\title{
The London Stock Exchange: Strategic Corporate Governance Restructuring After Demutualization
}

\author{
Laura Padilla Angulo, Groupe ESC Troyes en Champagne, France \\ Faten Ben Slimane, IRG Institute - University Paris-Est-Marne la Vallée, France \\ Djaoudath Alidou, Université de Bourgogne, France \& IUT de Parakou, Republic of Benin
}

\begin{abstract}
This study uses the London Stock Exchange (LSE), forced to demutualize due to major changes in its business environment, notably due to increased competition and technological advances, as field experiment to study corporate governance restructuring to adapt to new market conditions. The LSE improved its financial situation after demutualization and is an example of successful corporate governance restructuring. The LSE significantly restructured the composition of its board of directors following demutualization. The number of exchange members on the LSE board decreased after demutualization while the number of independent directors increased, pointing to a more "monitoring board", in support of an agency theory approach. Interestingly, the large majority of these independent directors had experiences in diverse business.
\end{abstract}

The LSE significantly reorganized its management team to adapt to the new strategies triggered by demutualization and modified its compensation by increasing performance-related payments. Results suggest that demutualization brings efficiencies if accompanied by changes in the governing bodies and in the incentive structures of the exchanges. Most of our results could be relevant also, for example, for firms going public, for smaller firms that are expanding their activities and searching for outside investors and for companies facing major changes in their business environments.

Keywords: Corporate Governance; Business Strategy; Demutualization; London Stock Exchange

\section{INTRODUCTION}

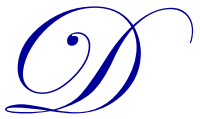

uring the past 20 years, globalization and financial integration, the development of innovative technology, regulatory reforms and changes in investment opportunities have all affected the environment for stock exchanges by increasing competition and affecting the functioning of financial markets. In response to the new financial environment, a growing number of stock exchanges have demutualized and opted to go public, which raises questions on the future of financial markets.

Most research on demutualization focuses on its impact on market performance. In comparison with mutual exchanges, demutualized and publicly listed exchanges generally operate more efficiently (Oldford \& Otchere, 2011), with improved financial performance, size and liquidity (Azzam, 2010; Otchere, 2006; Otchere \& AbouZied, 2008).

Stock exchanges governance critically affects their performance, but the subject has been overlooked since our review indicates that no previous research analyzes in detail the effect on corporate governance of the conversion from a mutual organization to a publicly traded self-listed exchange structure. This lack of attention can be partially explained by the difficulties of collecting detailed data on stock exchange corporate governance prior to demutualization. 
We analyze the case of the London Stock Exchange (LSE), one of the premiere exchanges in Europe and one of the first to formally demutualise and be fully listed. Moreover, the availability of very detailed and complete data on corporate governance allows us to do a fine-grained analysis over a relatively long period of time. The LSE significantly improved its financial results after demutualization and hence provides an example of successful corporate governance restructuring following major changes in the business environment.

Corporate governance (see Tricker, 2012, for a complete overview and discussion) essentially concerns the way power is exercised over corporate entities, including board activities and its relationship with shareholders or members, those managing the enterprise, and other legitimate stakeholders (Tricker, 2012, p. 4). We focus on the primary participants in these relationships: the board of directors and company management (led by the chief executive officer), who are central to corporate governance thinking and practice. We examine board composition, the structure of the LSE management team and management remuneration packages before and after demutualization.

We observe significant changes in the LSE's corporate governance after demutualization. In reorganizing its board, the exchange reduced the number of exchange members after demutualization and increased the number of independent directors, favoring a "monitoring board", in support of an agency theory approach, rather than a "stakeholder board". Most of the independent directors had experience in a variety of business, which relates to the concept of "board capital breadth" (Haynes \& Hillman, 2010) that captures, among other facets of board heterogeneity, work experience in other industries. Haynes and Hillman find that board capital breadth is positively associated with strategic change. Our results support their view.

The LSE also reorganized its management team to better adapt to new strategies triggered by demutualization, revising executive pay by increasing the fraction of performance-related payments to better align managerial and shareholder interests.

Despite being limited to one stock exchange, the evidence we provide offers insights that should help researchers better understand the workings behind improved stock exchange performance generally reported by previous empirical studies and attributed to demutualization. Most of our results are also relevant for firms going public, for smaller firms that are expanding their activities and searching for outside investors and for companies facing major changes in their business environments.

The next three sections review the literature on demutualization, introduce the case study of the London Stock Exchange, and present the hypotheses. We then present the data, methodology and empirical results. The final section discusses overall results and concludes.

\section{THE DEMUTUALIZATION OF STOCK EXCHANGES}

Traditionally, exchanges functioned as markets protected under national auspices because they represented national identities and enjoyed a monopolistic or near monopolistic position (see for example Doede, 1967; Pirrong, 2000). For a long time, exchanges were mutually-owned organizations where members were also owners of the exchange with all the voting rights given by ownership. This monopolistic market view of exchanges became progressively obsolete during the last 20 years due to powerful developments in the environment in which exchanges operate.

The key drivers of changes in the environment of exchanges are technological progress, especially the introduction of the Internet and the creation of innovative trading systems, and political reform (Elliott, 2002). Indeed, globalization contributed to increasing financial integration at the national and international levels and to reducing legal barriers to investing outside local financial markets. In Europe, financial competition was accelerated by the creation of the European Monetary Union and the introduction of the Investment Service Directive in 1993, replaced by the Markets in Financial Instruments Directive (known as MiFID) in 2007. These directives aimed to harmonize European securities laws and regulation of financial markets and ease remote access to trading platforms for investors in other European member states. 
With these changes in the financial environment, exchanges began to make focused efforts to attract investors and increase their market share. They had to rethink their traditional ownership structure in favor of a structure which accounts for the evolving exchange environment better (Aggarwal \& Dahiya, 2006) and reassess their business strategies to face growing market competition.

A growing number of exchanges (see Table 1) are opting to demutualize in the new environment, shifting from mutually-owned not-for-profit organizations into for-profit, investor-owned firms. This process offers the advantages of a separation between trading rights and ownership since shareholders provide capital to exchanges and receive profits but do not need to conduct trading on the exchange (Aggarwal, 2002).

With demutualization, the objectives of exchanges should, in principle, change from focusing primarily on the interests of members/brokers and keeping costs and investments limited to financing approved by members, to becoming firms that maximize profits by responding in a competitive manner to customer needs.

Table 1: Exchanges Demutualization

\begin{tabular}{|c|c|}
\hline Stock Exchange & Year \\
\hline Stockholm Stock Exchange & 1993 \\
\hline Helsinki Stock Exchange & 1995 \\
\hline Copenhagen Stock Exchange & 1996 \\
\hline Amsterdam Stock Exchange & 1997 \\
\hline Borsa Italiana & 1997 \\
\hline Australian Stock Exchange & 1998 \\
\hline Wiener Borse & 1999 \\
\hline Athens Stock Exchange & 1999 \\
\hline Iceland Stock Exchange & 1999 \\
\hline Liffe & 1999 \\
\hline Simex & 1999 \\
\hline Singapore Stock Exchange & 1999 \\
\hline Bolsas y Mercados Espanoles & 2000 \\
\hline CME & 2000 \\
\hline Hong Kong Stock Exchange & 2000 \\
\hline London Stock Exchange & 2001 \\
\hline NYMEX & 2000 \\
\hline Sydney Futures Exchange & 2000 \\
\hline Toronto Stock Exchange & 2000 \\
\hline Deutsche Börse & 2001 \\
\hline Euronext & 2001 \\
\hline Instinet & 2001 \\
\hline Nasdaq & 2001 \\
\hline Osaka Stock Exchange & 2001 \\
\hline Oslo Exchanges & 2001 \\
\hline Philippines Stock Exchange & 2001 \\
\hline Swiss Exchange & 2001 \\
\hline Tokyo Stock Exchange & 2001 \\
\hline Budapest Stock Exchange & 2002 \\
\hline International Stock Exchange & 2002 \\
\hline New Zealand Stock Exchange & 2002 \\
\hline Swiss Stock Exchange & 2002 \\
\hline Lima Stock Exchange & 2003 \\
\hline Bursa Malaysia & 2004 \\
\hline Pacific Exchange & 2004 \\
\hline Philadelphia Stock Exchange & 2004 \\
\hline Bombay Stock Exchange & 2005 \\
\hline CBOT & 2005 \\
\hline JSE & 2005 \\
\hline Korea Exchange & 2005 \\
\hline American Stock Exchange & 2006 \\
\hline Ljubljana Stock Exchange & 2006 \\
\hline
\end{tabular}


Table 1 cont.

\begin{tabular}{lc}
\hline Mexico Stock Exchange & 2006 \\
NYBOT & 2006 \\
NYSE & 2006 \\
Teheran Stock Exchange & 2006 \\
BOVESPA (Brazil) & 2007 \\
Boston Stock Exchange & 2007 \\
Bolsa da Colômbia & 2007 \\
Thai Exchange & 2008 \\
Tokyo Commodity Exchange & 2008 \\
Chicago Board Options Exchange & 2010 \\
Warsaw Stock Exchange & 2010 \\
Bucharest Stock Exchange & 2010 \\
Islamabad Stock Exchange & 2012 \\
\hline Source: World Federation of Exchanges, stock market reports and stock market official websites.
\end{tabular}

Source: World Federation of Exchanges, stock market reports and stock market official websites.

Demutualization can take different forms. The exchange can opt for a for-profit private company structure where only members or members and outside investors are the owners. The second option is to be a listed company with restrictions on the number of shares that can be owned by exchange members and non-members or, alternatively, without restrictions on trading. For most demutualized exchanges, a private structure is an intermediate step before becoming publicly traded, as with the Australian Stock Exchange, which began demutualization in September 1996 and was listed in October 1998. The London Stock Exchange and the Toronto Stock Exchange were fully listed one and two years after their demutualization in 2000.

A number of exchanges have now demutualized. As illustrated in Figure 1, the markets that have demutualized represent, in 2011, $83 \%$ of all stock markets in the world versus $38 \%$ in 1998. Most of these stock exchanges are located in North America and Europe. Over $44 \%$ are publically listed (WFE Cost and Revenue Survey, 2011).



Figure 1: Stock Exchanges by Organization Structure

There is relatively scant literature studying demutualization of stock exchanges. Most of the papers are theoretical and try to explain the advantages of conversion from a mutual non-profit to a for-profit investor-owned structure. The literature generally suggests that demutualization is the best strategy for exchanges to gain the flexibility and financing needed to compete in the global environment (Aggarwal, 2002). Demutualized stock exchanges can better access capital, respond to the fast-changing market place and facilitate the merger and acquisitions process (Aggarwal \& Dahiya, 2006; Lee, 2002, 2003; Steil, 2002). Hart and Moore (1996) show that transforming the exchange organization from a mutual to an outsider-owned structure contributes to increasing efficiency. By avoiding concentration of ownership power, Mendiola and O'Hara (2003) argue, demutualization resolves conflicts between the exchange and its members.

Most of the empirical literature on demutualization focuses on market performance. Schmiedel (2001, 2002) employs different methods of frontier efficiency in his two papers to analyze the efficiency of exchanges and 
includes the structure of these entities in the specification of his empirical model. Results are not conclusive. In his first paper, he finds a positive impact of demutualization on cost efficiency, and in his second paper he finds that mutual exchanges outperform demutualized exchanges in productivity. Serifsoy (2008) also studies the efficiency of exchanges, focusing on their governance, and finds that demutualized exchanges have higher technical efficiency than those with a mutual structure. However, he finds no evidence that publicly listed exchanges exhibit better efficiency than demutualized exchanges.

Other research focuses on the impact of demutualization on market microstructure, especially in terms of liquidity, order flows and transaction costs. Despite using different empirical methods and different samples, all the analyses report an improvement in liquidity after demutualization (Hazarika, 2005; Mendiola \& O'Hara, 2003; Treptow, 2006) and note that transaction costs decreased after demutualization (Krishnamurti, Sequeira, \& Fangjian, 2003). Aggarwal and Dahiya (2006) analyze the operating performance of 20 listed stock exchanges. Using different performance measures, including first day return, return on equity and operating margin, they find that most exchanges improved performance after listing. Otchere and Abou-Zied (2008) analyze the demutualization process of the Australian Stock Exchange and find that the conversion from mutual to publicly traded exchange was beneficial for the stock market in terms of operating performance and market liquidity. These results were confirmed more recently by Azzam (2010) and Oldford and Otchere (2011).

But the conversion to a demutualized structure, although benefits accrue, brings new conflicts of interest due to the commercial nature of the exchanges and their explicit objective to maximize profits. A risk of conflict of interest may exist between exchanges' regulatory role (surveillance of the markets and its participants, controlling and regulating trading, managing listings and admission to trading, etc.) and their profit objectives. Exchanges' listing, trading and clearing fees, which are the main sources of revenue and represent more than $67 \%$ of total revenue $^{1}$, come from the principal participants of exchanges: issuers, dealers and intermediaries. Under pressure to meet shareholders' expectations and increase profits, a demutualized exchange may have less incentive to take actions against principal participants since they are the main source of revenue. This situation raises questions about the ability of the for-profit exchange to develop and implement appropriate listing, trading and admission standards, market surveillance and equitable treatment of customers. This conflict of interest may be more serious in an increasingly competitive environment where the exchanges may be pressed to reduce their regulatory, listing and disclosure criteria to better compete with other exchanges and attract more financial participants (IOSCO, 2001; Steil, 2002; Worthington \& Higgs, 2006). These fears have been partially mitigated by the results of the empirical study of Reiffen and Robe (2011). They demonstrate that the exchange objective to maximize revenues does not conflict with, but depends on, the ability to implement strong trade practice rules.

To reduce conflicts of interest, demutualized exchanges are encouraged by regulatory institutions to take a number of measures, including the establishment of a rigorous regulatory framework and issuing a clear legal statement of the role of the exchange in providing fair and efficient "public good". Demutualized entities also need to strengthen corporate governance requirements and the board should be more responsible for the integrity of the regulatory process (IOSCO, 2001).

Following demutualization, some exchanges opted for a partial or total separation of their commercial activities from regulatory functions. After demutualization, for example, the Hong Kong Stock and Futures Exchanges transferred certain market regulation functions to the Securities and Futures Commission (SFC).

\section{THE LONDON STOCK EXCHANGE SETTINGS}

The LSE, officially found in 1801, has witnessed many changes affecting its functioning and regulation. One of the most important reforms occurred on 27 October, 1986 with market deregulation, known as the "Big Bang." Regulatory reforms included the abolishment of fixed commissions and the end of the voting rights system enjoyed by LSE individual members up until then. The ownership of member firms by outside corporations was allowed and all firms were able to operate both as broker and dealer. Deregulation was accompanied by technical reforms to modernize trading systems by introducing computers in the trade. These reforms made the exchange less

\footnotetext{
${ }^{1}$ Data provided by the 2011 Cost and revenue Survey, World Federation of Exchanges.
} 
of a "club" and more of an international center of capital markets. Under the Companies Act 1985, the Exchange became a private limited company. The last of these reforms was the replacement of the governing council in 1991 by a board of directors comprising executives, customers and users of the Exchange.

In July 1999, the LSE announced its intention to demutualize and become a publicly limited company that operated on a fully commercial basis. According to the LSE, the new demutualized structure would help the exchange respond better not only to consumer needs but also to changes in the financial environment due to increasing competition from electronic trading systems. The separation of ownership from membership was intended to provide customers with the right services, create value for shareholders, and give the exchange more flexibility to respond to environment changes. Demutualization was approved by shareholders. In March 2000, the LSE became the "London Stock Exchange plc" and went public one year later, with a market capitalization of more than 2164 USD billion. Following public listing, LSE ownership by institutional investors increased rapidly from the original 15 -to-20\% of shares outstanding to $25 \%$ just one year later (2002) and to more than $66 \%$ in 2012.

After exchange demutualization, the new LSE board urged the UK economics and finance ministry (commonly known as HM Treasury) to enact regulatory reforms. Traditionally, the LSE had two functions: to regulate, under the Financial Services Act (FSA), LSE trading in two markets (the main market and the Alternative Investment Market, AIM), and to regulate listings in the primary market through the UK Listing Authority (UKLA). Following demutualization, the LSE's role as regulator of the primary market was transferred to the FSA. However, the LSE continues to regulate secondary markets, assisted by the Exchange's Regulatory News Service (RNS) and the UK Listing Authority.

Table 2: LSE Major Financial Performance Indicators

\begin{tabular}{lccccccc}
\hline \multicolumn{1}{c}{ (in billions of USD) } & $\begin{array}{c}\text { Total } \\
\text { Revenue }\end{array}$ & $\begin{array}{c}\text { Trading } \\
\text { Volume }\end{array}$ & $\begin{array}{c}\text { Market } \\
\text { Capitalization }\end{array}$ & $\begin{array}{c}\text { Number of } \\
\text { Listed } \\
\text { Companies }\end{array}$ & $\begin{array}{c}\text { ROA } \\
(\%)\end{array}$ & $\begin{array}{c}\text { Net Income } \\
\text { Margin } \\
(\%)\end{array}$ & $\begin{array}{c}\text { Turnover } \\
\text { Velocity } \\
(\%)\end{array}$ \\
\hline Prior to demutualization & .234 & $2,849.751$ & $2,295.825$ & 2442 & 15.31 & 12.64 & 51.5 \\
Post-demutualization & .488 & $5,205.900$ & $2,806.798$ & 2940 & 15.71 & 23.93 & 111.08 \\
Difference & $.253^{* * *}$ & $2,356.148^{*}$ & 510.973 & $498^{* * *}$ & .39 & $11.29^{* * *}$ & $59.58^{* * * *}$ \\
P Value & .00 & .02 & .22 & .00 & .88 & .01 & .00 \\
\hline
\end{tabular}

Data come from LSE annual reports, WFE and Thomson One database. ${ }^{*} \mathrm{p}<.05,{ }^{* *} \mathrm{p}<.01,{ }^{* * *} \mathrm{p}<.001$. This table contains the mean financial performance of the LSE. The prior to demutualization indicators are the mean indicators for the five-year prior to demutualization and the post-demutualization indicators are the mean indicators for the five years following the demutualization and the self-listing of the LSE. The turnover velocity is the ratio between the Electronic Order Book (EOB) turnover of domestic shares and their market capitalization.

Demutualization seems to have contributed to improve the financial situation of the Exchange. When we look at the five years prior to demutualization, we find that major financial indicators of the LSE improved in the five years following demutualization. The post-conversion mean for total revenue, trading volume and market capitalization considerably outperformed the mean prior to demutualization (Table 2) and both profitability and performance ratios of the LSE improved after demutualization. The LSE mean ROA, net income margin and turnover velocity were $15.31 \%, 12.64 \%$ and $51.5 \%$, respectively, prior to demutualization while they were $15.71 \%$, $23.93 \%$ and $111.08 \%$, respectively, after demutualization (difference $.39 \%$, p-value .88 ; difference $11.29 \%$, p-value .01 and difference $59.58 \%$, p-value .00 respectively). Moreover, demutualization also helped attract more listed firms to the exchange. The post-conversion mean for the number of listed firms increased by $20 \%$ after demutualization. These results suggest that investors have benefited from LSE demutualization and self-listing strategies.

The commercial nature of the demutualized exchanges prompted many to look for diversified services and new strategies to generate more revenue (Mendiola \& O'Hara, 2003). Exchanges introduced performing trading platforms to ease access for institutional and foreign investors and established different types of cooperation with other exchanges, at times even merging with one another (Serifsoy, 2008).

In this spirit, the LSE launched a web price service (Prism) in 2000 which offers free daily price updates to assist private investors. For both professional and private investors, the exchange also created, in 2000, extraMARK, a new market that specializes in innovative products. To further its internationalization, the LSE began promoting its 
markets internationally (TechMARK and AIM) in 2001 through advertising, investor roadshows and seminars. The exchange expected to become the leader in international investment capital. The exchange promotes electronic shareholding trough the development, for instance, of a high-capacity network for customers using internet protocol (IP) communications technology.

To attract more international investments, the LSE signed many contracts of cooperation to ease access of foreign companies to London capital markets. Since 2002, the LSE has attracted growing companies from New Zealand, the Nordic regions, Russia and Canada, among others. The exchange also strengthened its position in AsiaPacific by opening a regional office in Hong Kong in 2004 to attract Asian companies, especially Chinese companies, to London's international market. The LSE and Tokyo Stock Exchanges established a new market in 2008 for emerging companies which is operated by a joint venture in Tokyo.

The LSE continued its strategy of internationalization by signing memorandums of understanding (MOU) with many exchanges to improve their international presence and facilitate trading in multiple markets. For instance, in 2007 the LSE signed cooperation agreements with the Tel Aviv Stock Exchange, the Tokyo Stock Exchange and the Bahrain Stock Exchange (BSE). During the same year, facing increasing competition in Europe, the LSE acquired the Italian Stock Exchange in response to the merger between the NYSE Group and Euronext, which created the largest exchange in the world in market capitalization. The LSE is continuing its strategy of internationalization, although it has been a target of failed mergers with Deutsche Börse, the Nasdaq, OMX Group and the Canadian Stock Exchange (TMX).

\section{HYPOTHESIS DEVELOPMENT: HOW DEMUTUALIZATION MAY AFFECT CORPORATE GOVERNANCE}

Exchanges demutualize to decouple ownership from members and separate the interests of the exchange from those of its members. The member-owned association structure fails to provide the flexibility and financing needed to compete today (Aggarwal, 2002) and to adapt to changing circumstances. As Domowitz and Steil (1999) argue, members may resist innovations, even if they would enhance exchange value, if the changes reduce demand for members' intermediation services. Exchange members "resisted changes if these entailed additional costs, loss of revenue or competitive threat" when run as mutual associations. (Akhtar, 2002, p. 12). Several studies document cases where reforms in exchanges in the US, Europe and other regions have been hindered by the lack of consensus among their members (e.g. Cybo-Ottone, Di Noia, \& Murgia, 2000; Hart \& Moore, 1996). When ownership of the exchange is separated from membership under demutualization, it is not appropriate that trading members have exclusive authority over exchange decisions (Akhtar, 2002).

The main task of the board is to direct the company, including strategy formulation and policy making (Tricker, 2012). It follows that exchanges can decrease the influence of trading members on corporate decisions by decreasing their representation on the board and replacing them by other type of directors who are more willing to consider appropriate competitive strategies.

Drawing on these arguments, we test the following hypothesis:

Hypothesis 1: The number of exchange members on the LSE board of directors has decreased since demutualization and the board has diversified.

We explore two possible results. Once companies go public, the compliance role of the board tends to dominate and an independent board helps to legitimize this role. Corporate governance codes for good practice call for a wider use of independent non-executive directors, defined as 'independent of management and free from any business or other relationship which could ultimately interfere with the exercise of independent judgment (...)' (UK's Cadbury Report, 1992). Independent directors are expected to provide oversight and supervision of executive activities, the achievement of corporate objectives and compliance with corporate governance requirements. To ensure effective supervision and auditing of management, a majority of board members should be truly independent.

All these arguments draw on Jensen and Meckling's agency theory (1976), which was the first to theorize about the functions of non-independent (insider) directors and independent (outsider) directors on boards. Agency 
theory views the governance relationship as a contract between shareholders and managers. It argues that managers seek to maximize their own personal benefit, to take actions advantageous to themselves and detrimental to the shareholders. Based on these arguments, we examine if the LSE increased the proportion of independent directors after demutualization to create a board where a majority were independent. We term this type of board a "monitoring board."

Critics of this type of board structure suggest that, in practice, it gives too much power to the executive directors by making them responsible for strategy as well as the day-to-day running of the enterprise (Tricker, 2012). They contend that outside directors are inevitably pushed into a conformance and compliance mode rather than contributing to strategy formulation and policy-making. The reason for this lack of contribution to strategy formulation from outside directors is that they "may not have the relevant expertise or skills to add significantly to a board's work, precisely because of their independence" (Lee, 2010, p. 280).

Other commentators believe that an exchange's board should include representatives from major interest groups (Holthouse, 2002), or stakeholders, given the for-profit motive. These stakeholders are, by definition, not independent. These arguments draw on stakeholder theory (Freeman, 1984), which identifies and models the groups which are stakeholders of a corporation and both describes and recommends methods by which companies can account for the interests of these groups. Previous to this theory, Jones and Goldberg (1982) had already argued that the presence of stakeholder directors on corporate boards is one of the most direct means for firms to incorporate stakeholder interests in corporate decision-making.

The other possible effect of demutualization we examine is whether the LSE opted for a "stakeholder board," by increasing the number of new stakeholders given the for-profit motive of the exchange after demutualization. We focus on two types of stakeholders that are particularly relevant in the new for-profit condition of exchanges: LSE institutional investors (LSE shareholders) and LSE customers (listed companies).

LSE new investors are clearly stakeholders. For customers, a stock exchange demutualization creates a corporation that operates, ideally, in a customer-focused manner and can respond more easily and quickly to changes in the business environment (Hughes, 2002).

Customers become even more important stakeholders after demutualization. We choose to examine listed companies as customers because, as Aggarwal (2002) explains, as competition among exchanges intensifies, trading commissions are likely to produce the most revenue and the key to an exchange's success in generating commissions depends on generating trading volume. By increasing the number of listed companies, exchanges attract more orders and provide more liquidity to investors.

Besides appropriate board representation, it is important that the exchange executive team must have the expertise and skills to implement new strategies enabling stock exchanges to efficiently compete in the more competitive environment.

Demutualization involves transferring considerable exchange ownership and decision-making power from members to outside investors. As Aggarwal puts it, this means that "the old consensus decision-making of the exchange members is eventually going to be supplanted by a professional management team" Aggarwal (2002, p. 108). We expect the new investors to encourage appointment of a professional management team with competences better adapted to the new profit-seeking strategies. In this rapidly developing environment, competences other than the traditional ones in financial markets become especially relevant (Holthouse, 2002), including knowledge of information systems, product development and commercial experience. We expect to observe LSE management restructuring of executives' backgrounds after demutualization.

Hypothesis 2: Following demutualization, the LSE executive team restructured to increase the proportion of managers with competences better adapted to the new business environment and strategies.

The new executive team replacing the old decision-making system of the exchange members is going to be "presumably motivated by significant share ownership to increase efficiency and profits" (Aggarwal, 2002, p. 108). 
In line with this argument, we expect that the nature of LSE investors after demutualization will prompt the board to revise executive remuneration packages to motivate them to increase efficiency, profits and shareholder value since exchanges are no longer monopolies and must run as efficient business companies. Management must have the right incentives to adapt and reinforce the new commercial culture of the exchanges after demutualization.

As suggested by agency theory, executive and shareholder interests can be aligned by linking management remuneration to corporate performance objectives. We expect to see an increase in the proportion of remuneration for LSE management related to performance objectives following demutualization.

Hypothesis 3: Following demutualization, the proportion of the remuneration package of the LSE executive team related to financial performance has increased.

\section{DATA AND METHODOLOGY}

\subsection{Data Sources}

The data on LSE board characteristics, including individual LSE directors, come mostly from LSE annual reports. The data were completed with LSE press releases and information in the corporate governance section on the LSE website and with information from Bloomberg BusinessWeek, Forbes, Reuters and company-directorcheck.co.uk databases online. The information on LSE institutional investors and LSE listed companies comes from the database on the LSE website and from email exchanges with LSE support staff. The information on the remuneration packages of LSE management comes from the remuneration report in LSE annual reports.

\subsection{Methodology and Measures}

For testing the three hypotheses, we compare the pre-demutualization mean (1996 to 2000) to the postdemutualization mean (2002 to 2007) of the relevant measures, as explained in detail below. We calculate the difference in means and report the two tail p-statistic from a paired t-test performed to check for the significance of the differences in means.

\subsubsection{Board Composition Measures}

We calculate the share of executive directors, non-executive directors, independent non-executive directors, the ratio of independent non-executive directors over non-executive directors, the share of member firms, investors ${ }^{2}$ and listed companies represented on the LSE board of directors. We also report the share of foreign directors.

\subsubsection{Executive Team Competences Measures}

We calculate the proportion of managers on the executive team with traditional competences in financial markets, namely banking, stock brokerage, funds/investment management and securities. We also calculate a general competence measure we call finance which integrates all the previous competences and includes other finance experience. We calculate the proportion of managers with competences especially relevant for new LSE strategies (development of more efficient electronic trading systems, expansion of direct trading access for foreign investors, increases in the number of innovative products, alliances and mergers), which include information systems, marketing and sales, product development and commercial corporate communications, international and legal experience. We analyze CEO competences separately.

\subsubsection{Executive Team Remuneration Package Measures}

We calculate the fraction of executive remuneration that is variable and dependent on the achievement of performance targets which align with shareholders' interests. The performance-related component of executive remuneration includes:

\footnotetext{
${ }^{2}$ Substantial shareholders notified of $3 \%$ holding or more according to LSE annual reports.
} 
1. Annual bonus, including cash payment and, in certain circumstances, a deferred award of shares, determined by two factors: the performance of the company against annual financial targets which include operating profit, earnings per share and cash flows and individual performance against personal objectives.

2. Share option grants to reward the creation of long-term shareholder value.

The fixed components include base salary, benefits and provisions for retirement.

\section{RESULTS}

Table 3 shows the composition of the LSE board before and after demutualization.

Table 3: Board Composition Before and After Demutualization

\begin{tabular}{lcccc}
\hline & $\begin{array}{c}\text { Prior-to } \\
\text { Demutualization }\end{array}$ & $\begin{array}{c}\text { Post- } \\
\text { Demutualization }\end{array}$ & Difference & p-value \\
\hline Executive directors & $22 \%$ & $23 \%$ & $1 \%$ & .41 \\
Non-executive directors & $78 \%$ & $77 \%$ & $-1 \%$ & .41 \\
Independent non-executive directors & $27 \%$ & $53 \%$ & $26 \%$ & .00 \\
Independent non-executive directors/non- & $34 \%$ & $68 \%$ & $34 \%^{* * *}$ & .00 \\
executive directors & $34 \%$ & $13 \%$ & $-21 \%^{* *}$ & .01 \\
Members & $0 \%$ & $0 \%$ & $0 \%$ & NA \\
Investors & $51 \%$ & $46 \%$ & $-5 \%$ & .59 \\
Listed & $6 \%$ & $23 \%$ & $17 \%$ & .00 \\
Foreign & & & $17 \%$ \\
\hline
\end{tabular}

$\overline{\mathrm{p}}<.10,{ }^{*} \mathrm{p}<.05,{ }^{* *} \mathrm{p}<.01,{ }^{* * * *} \mathrm{p}<.001$.

The number of foreign directors significantly increased after demutualization: the mean proportion of foreign directors prior to demutualization was $6 \%$ while after demutualization it is $23 \%$ (difference $17 \%$, p-value .00 ), one of the foreign directors being the CEO. These results support the view that the LSE opted for a more international board, in line with its internationalization strategy.

Following demutualization, the LSE board has a majority of independent non-executive directors. Critics of boards with a majority of independent directors suggest that these independent directors are pushed into a conformance and compliance mode rather than contributing positively to the performance aspects of strategy formulation. This dominance of the compliance role over the strategic role occurs because the independent directors typically lack the industry-specific knowledge that their senior-executive counterparts have. To confirm this, we examine the competences of independent non-executive directors on the LSE board before and after demutualization, shown in Table 4.

Table 4: Independent Non-Executive Directors Competences Before and After Demutualization

\begin{tabular}{|c|c|c|c|c|}
\hline & $\begin{array}{c}\text { Prior-to } \\
\text { Demutualization } \\
\end{array}$ & $\begin{array}{c}\text { Post- } \\
\text { Demutualization } \\
\end{array}$ & Difference & p-value \\
\hline \multicolumn{5}{|c|}{ Traditional Competences Financial Markets: } \\
\hline Stock-Broking & $62 \%$ & $0 \%$ & $-62 \%^{* * *}$ & .00 \\
\hline Banking & $62 \%$ & $19 \%$ & $-43 \%^{* * *}$ & .00 \\
\hline Funds Management and Securities & $65 \%$ & $38 \%$ & $-28 \%{ }^{* * * *}$ & .00 \\
\hline Financial & $100 \%$ & $81 \%$ & $-19 \%^{* * *}$ & .00 \\
\hline \multicolumn{5}{|l|}{ LSE New Strategy-Related Competences: } \\
\hline Information Systems & $0 \%$ & $0 \%$ & $0 \%$ & NA \\
\hline Marketing and Sales & $4 \%$ & $0 \%$ & $-4 \%$ & .30 \\
\hline Product Development and Commercial & $0 \%$ & $0 \%$ & $0 \%$ & NA \\
\hline Corporate Communications & $0 \%$ & $0 \%$ & $0 \%$ & NA \\
\hline International & $42 \%$ & $53 \%$ & $11 \%^{\dagger}$ & .09 \\
\hline Diverse Businesses & $24 \%$ & $81 \%$ & $57 \%^{* * *}$ & .00 \\
\hline Legal & $0 \%$ & $38 \%$ & $38 \%^{* * * *}$ & .00 \\
\hline
\end{tabular}


We see an important decrease in the independent directors' competences in financial markets. The most remarkable observation is the absence of independent directors with stockbrokerage competences after demutualization, while prior to demutualization $62 \%$ of the independent non-executive directors had stock brokerage competences (difference -62\%, p-value .00). Prior to demutualization, $62 \%$ of independent non-executive directors had banking competences while only $19 \%$ after demutualization did (difference $-43 \%$, p-value .00). Before demutualization, $65 \%$ of the independent non-executive directors had funds management and securities competences while only $38 \%$ did after demutualization (difference $-28 \%$, p-value .00 ).

Due to the lack of industry-specific knowledge by independent directors, one of the greatest challenges independent directors face is to stay fully informed about the companies on whose boards they serve (George, 2013). The lack of industry-specific knowledge has been mitigated in the LSE by a combination of initiatives involving frequent communication between the LSE executive management team and independent directors. The LSE annual reports note that the executive management team informs the LSE board about their business responsibilities on a regular basis and participates in the board's periodic strategy sessions. The LSE also schedules offsite strategy board sessions. The LSE chairman meets non-executive directors without the presence of executive directors on a number of occasions throughout the year.

We expect that these meetings help to avoid independent directors' conformance by allowing directors to discuss privately any concerns they may have about LSE management and to ask for improved governance initiatives or additional reviews.

With regard to new strategy-related competences, the most salient result is the significant increase in the proportion of independent non-executive directors with diverse business experience, more than tripling after demutualization and representing the large majority of non-executive independent directors. The mean proportion of independent non-executive directors with diverse business experiences prior to demutualization was $24 \%$ while after demutualization it is $81 \%$ (difference $57 \%$, p-value .00). Diverse business experience relates to the concept of "board capital breadth," according to Haynes and Hillman (2010), which captures, among other facets of board heterogeneity, work experience in other industries. Haynes and Hillman find that board capital breadth is positively associated with strategic change. In support of this view, Golden and Zajac (2001) note that boards with a wider array of director experiences are likely to consider a broader array of strategic options. This is particularly relevant for the LSE, which made strategic changes after demutualization to better adapt to the evolving exchange environment. The presence of directors with experiences in diverse businesses may have triggered the implementation of these changes in LSE strategies.

Table 5 shows executive team competences before and after demutualization. Consistent with Hypothesis 2 , the number of managers on the LSE executive team with strategy-related competences significantly increased after demutualization. The most salient results are the significant increases in the presence of managers with competences in information systems, which prior to demutualization was 3\%, while after demutualization $41 \%$ (difference $38 \%$, p-value .00), product development and commercial, which prior to demutualization was zero while after demutualization it is $49 \%$ (difference $49 \%$, p-value .00) and international experience, which prior to demutualization was $3 \%$ while after demutualization it is $53 \%$ (difference $50 \%$, p-value .00). Likewise, the number of managers with marketing and sales competences has also significantly increased, from zero prior to demutualization to $26 \%$ after demutualization (difference $26 \%$, p-value .00). The number of managers with corporate communications competences increased from zero prior to demutualization to $10 \%$ after demutualization (difference $10 \%$, p-value .00). The LSE in effect reorganized its management structure to enhance strategic development resulting from its more commercially-focused operations. The new competences of the LSE management team are better adapted to focus on customer needs, meet technology-driven marketplace demands and enhance internationalization. 
Table 5: Executive Team Competences Before and After Demutualization

\begin{tabular}{|c|c|c|c|c|}
\hline & $\begin{array}{c}\text { Prior-to } \\
\text { Demutualization } \\
\end{array}$ & $\begin{array}{c}\text { Post- } \\
\text { Demutualization }\end{array}$ & Difference & p-value \\
\hline \multicolumn{5}{|c|}{ Traditional Competences Financial Markets: } \\
\hline Stock-broking & $6 \%$ & $13 \%$ & $7 \%$ & .39 \\
\hline Banking & $3 \%$ & $23 \%$ & $20 \% *$ & .05 \\
\hline Funds Management and Securities & $0 \%$ & $31 \%$ & $31 \%$ *** & .00 \\
\hline Financial & $80 \%$ & $79 \%$ & $-1 \%$ & .95 \\
\hline \multicolumn{5}{|c|}{ LSE New Strategy-Related Competences: } \\
\hline Information Systems & $3 \%$ & $41 \%$ & $38 \%{ }^{* * *}$ & .00 \\
\hline Marketing and Sales & $0 \%$ & $26 \%$ & $26 \%{ }^{* * *}$ & .00 \\
\hline Product Development and Commercial & $0 \%$ & $49 \%$ & $49 \%$ *** & .00 \\
\hline Corporate Communications & $0 \%$ & $10 \%$ & $10 \%$ *** & .00 \\
\hline International & $3 \%$ & $53 \%$ & $50 \%$ *** & .00 \\
\hline Diverse Businesses & $21 \%$ & $4 \%$ & $-17 \% *$ & .02 \\
\hline Legal & $10 \%$ & $0 \%$ & $-10 \% *$ & .03 \\
\hline
\end{tabular}

LSE changed its CEO after demutualization. Gavin Casey, the CEO from 1996 to 2000, was a chartered accountant with extensive experience in the finance and insurance industry, including banking, venture capital, corporate finance and securities. Prior to joining the LSE, Mr. Casey held various managerial positions in the securities sector, including group finance director and chief operating officer of the securities house Smith New Court PLC (acquired by Merril Lynch in 1995).

He resigned on 15 September 2000, one day after shareholders, who opposed his plan to merge with Germany's Deutsche Boerse, turned on him at the annual meeting and called for him to step down (English, 2000). The LSE appointed Clara Furse CEO in January $2001^{3}$, the first woman and the first foreigner (born in Canada to Dutch parents and educated at schools in Colombia, Denmark and Britain) to occupy the position. She had extensive experience in global financial markets. She began her career as a broker and held various managerial positions in the global financial services sector, including executive and managing director, global head of Futures in Phillips \& Drew (now UBS) and CEO of Rand Merchant Bank, Credit Lyonnais Rouse.

Her international background, business experience and information technology expertise were specially relevant competences for the new LSE, including the internationalization focus and the creation of additional revenue by exploiting technology and information services.

Table 6 shows the ratio of performance related compensation to total compensation of LSE management before and after demutualization. Consistent wih Hypothesis 3, the part of the remuneration package of LSE executive team members related to financial performance significantly increased after demutualization, from $30 \%$ before to $85 \%$ after demutualization (difference $56 \%$, p-value .00).

Table 6: Performance Related Compensation of Management Before and After Demutualization

\begin{tabular}{lcccc}
\hline & Prior-to Demutualization & Post-Demutualization & Difference & p-value \\
\hline Performance-related compensation & $30 \%$ & $85 \%$ & $56 \%$ & .00 \\
\hline${ }^{\dagger} \mathrm{p}<.10,{ }^{*} \mathrm{p}<.05,{ }^{* *} \mathrm{p}<.01,{ }^{* * * *} \mathrm{p}<.001$. & & & &
\end{tabular}

The LSE extensively reviewed its remuneration policy to meet its governing objective of maximising shareholder value after demutualization. The exchange introduced several long term incentive plans in remuneration packages, taking the form of annual bonuses and share options grants to reward the creation of long term shareholder value. As a result, remuneration is predominantly performance-related now, reflecting the commitment to pay for performance and reward the management team only when performance goals are achieved.

\footnotetext{
${ }^{3}$-In the meantime Don Cruickshank assumed executive responsibility, supported by Martin Wheatley, Director of Business Development and Jonathan Howell, Director of Finance. LSE press release, 24 January 2001.
} 


\section{DISCUSSION AND CONCLUSION}

Following the wave of stock exchange demutualization during the last decade, we can draw lessons that may be useful to developing countries. The LSE was one of the first to demutualize, succesfully adapting to new market conditions and improving financial performance, according to major financial indicators. Therefore, it is an interesting case for the analysis of the impact of demutualization on corporate governance of stock exchanges and, more generally, for the analysis of corporate governance restructuring to adapt to new business environments.

Previous research on the demutualization of stock exchanges, which focuses primarily on financial performance, in general indicates that demutualization improves performance. The corporate governance of exchanges has often been overlooked, although it significantly affects performance. However, since the financial crisis that began in 2007, the governance of financial infrastructure institutions, including stock exchanges, is now seen as critically important.

Demutualization separates ownership from membership that automatically provides trading rights. Ideally, demutualization should help to introduce effective corporate governance, but this is only possible if it is accompanied by improvements in the incentive structure, decision-making and effective oversight of a governing board and a company structure (Akhtar, 2002). These improvements imply changes in the main decision-making bodies of corporations: the board of directors and the executive team. This is what we analyse in this study.

Our results show that the LSE changed its board composition after demutualization, favoring a more "monitoring board," with an increased number of independent directors, over a "stakeholder board," probably to avoid conflicts of interest risks. Most of the new independent directors had experience in diverse businesses, suggesting that their experience may have triggered the implementation of significant changes in LSE strategies. The LSE also reorganized its management team and its remuneration packages to adapt to the new strategies.

Although we must be cautious about generalizing from the LSE case study to other demutualized exchanges, our analysis suggests that demutualization processes bring efficiency if accompanied by changes in governing bodies and incentive structures, consistent with Akhtar (2002). Our findings are also consistent with arguments by Shleifer and Vishny (1997) that improved corporate governance may contribute to the reputation and credibility of an organization and enhance its financial performance.

Most of our results may apply to firms going public, to smaller firms that are expanding their activities and searching for outside investors and for companies facing major changes in the business environment. Our results suggest that combining an independent board with significant restructuring of the top management to implement competitive strategies, along with revised executive pay packages, is a strategy that brings efficiencies.

Future research could extend our analysis by studying the effects of demutualization on the corporate governance of other exchanges. Theoretical and empirical research on corporate governance suggests that differing institutional frameworks affect the structure of firms (Shleifer \& Vishny, 1995). With regard to the evolution of exchange boards, future researchers could focus on the incorporation of other legitimate stakeholders.

\section{ACKNOWLEDGEMENT}

We thank Nanci Healy for proof reading the article and for her valuable comments. We thank two anonymous referees for comments that greatly improved this article. All errors are ours.

\section{AUTHOR INFORMATION}

Laura Padilla Angulo is Assistant Professor of Economics at the Groupe ESC Troyes en Champagne, France. In 2007, she obtained her PhD in Economics at MPSE-University of Toulouse I (now Toulouse School of Economics), France, with a dissertation on the deregulation of US freight railroads. Her main research interests are: corporate governance, business strategy and entrepreneurship. E-mail: laura.padilla@get-mail.fr (Corresponding author) 
Faten Ben Slimane is Assistant Professor, Department of Economics and Business at the University of Paris-Est Marne-La-Vallée, France. In 2010, she obtained her PhD in Economics at the University of Paris Dauphine with the dissertation on the consolidation of stock exchanges. Her main research interests are: financial markets, corporate governance and business strategy. E-mail: faten.benslimane@u-pem.fr

Djaoudath Alidou is Assistant Professor in Finance Economics at the University of Parakou (Republic of Benin). She obtained a PhD in Finance at IAE Dijon - University of Bourgogne, France. Her dissertation was about the determinants of employees' equity issues in a French context. Her main research interests are: corporate finance, corporate governance, employee ownership. E-mail: djaourdath@gmail.com

\section{REFERENCES}

1. Aggarwal, R. (2002). Demutualization and corporate governance of stock exchanges. Journal of Applied Corporate Finance, 15, 105-113.

2. Aggarwal, R., \& Dahiya, S. (2006). Demutualization and public offerings of financial exchanges. Journal of Applied Corporate Finance, 18, 105-113.

3. Akhtar, S. (2002). Demutualization of Asian stock exchanges - Critical issues and challenges. In Shamshad Akhtar (Ed.), Demutualization of stock exchanges- Problems, solutions and case studies (pp. 3-29). Manila: Asian Development Bank.

4. Azzam, I. (2010). Stock exchange demutualization and performance. Global Finance Journal, 21, 211-222.

5. Cadbury, Sir Adrian (1992). The financial aspects of corporate governance: A report of the committee on corporate governance. London: Gee \& Co.

6. Cybo-Ottone, A., Di Noia, C., \& Murgia, M. (2000). Recent development in the structure of securities markets. In R. E. Litan, \& A. M. Santomero (Eds.), Brookings-Wharton Papers on Financial Services 2000 (pp. 223-282). New York: Brookings Institution Press.

7. Doede, R. W. (1967). The monopoly power of the New York stock exchange. (Unpublished PhD dissertation). University of Chicago.

8. Domowitz, I., \& Steil, B. (1999). Automation, trading costs, and the structure of the securities trading industry, in R. E. Litan, \& A. M. Santomero (Eds.), Brookings-Wharton Papers on Financial Services 1999 (pp. 33-81). Washington, DC: Brookings Institution Press.

9. Elliott, J. (2002). Demutualization of securities exchanges: a regulatory perspective. IMF Working Paper No. 02/119. International Monetary Fund, Washington DC.

10. $\quad$ English, S. (2000). Casey falls on his sword. The Telegraph, September 16.

11. Freeman, R. E. (1984). Strategic Management: a Stakeholder Approach. Boston: Pitman.

12. George, W. (2013). Board governance depends on where you sit. The McKinsey Quarterly, February.

13. Golden, B. R., \& Zajac, E. J. (2001). When will boards influence strategy? Inclination x power = Strategic change. Strategic Management Journal, 22, 1087-1112.

14. Jensen, M. C., \& Meckling, W. H. (1976). Theory of the firm: Managerial behavior, agency costs and ownership structure. Journal of Financial Economics, 3, 305-360.

15. Jones, T. M., \& Goldberg, L. D. (1982). Governing the large corporation: More arguments for public directors. Academy of Management Review, 7, 603-611.

16. Hart, O., \& Moore, J. (1996). The governance of exchanges: Members'cooperatives versus outside ownership. Oxford Review of Economic Policy, 12, 53-69.

17. Haynes, K., \& Hillman, A. (2010). The effect of board capital and CEO power on strategic resource allocation. Strategic Management Journal, 31, 1145-1163.

18. Hazarika, S. (2005). Governance change in stock exchanges. Working Paper, Baruch College, City University, New York.

19. Holthouse, D. (2002). The structure of a demutualized exchange - The critical issues. In Shamshad Akhtar (Ed.), Demutualization of stock exchanges- Problems, solutions and case studies (pp. 73-83), Manila: Asian Development Bank.

20. Hughes, P. S. (2002). Background information on demutualization. In Shamshad Akhtar (Ed.), Demutualization of stock exchanges- Problems, solutions and case studies (pp. 33-47), Manila: Asian Development Bank. 
21. International Organization of Securities Commissions (IOSCO), Technical Committee (2001). Issues paper on exchange demutualization, Madrid, June.

22. Krishnamurti, C., Sequeira, J., \& Fangjian, F. (2003). Stock exchange governance and market quality. Journal of Banking and Finance, 27, 1859-1878.

23. Lee, R. (2010). Running the world's markets the governance of financial infrastructure. Princeton: Princeton University Press.

24. London Stock Exchange. 1996-2007. Annual Reports.

25. Mendiola, A., \& O'Hara, M. (2003). Taking stock in stock markets: The changing governance of exchanges. Working Paper, Cornell University- Samuel Curtis Johnson Graduate School of Management. Available at SSRN: http://papers.ssrn.com/sol3/papers.cfm?abstract_id=431580

26. Oldford, E., \& Otchere, I. (2011). Can commercialization improve the performance of stock exchanges even without corporatization? Financial Review, 46, 67-87.

27. Otchere, I. (2006). Stock exchange self-listing and value effects. Journal of Corporate Finance, 12, 926953.

28. Otchere, I., \& Abou-Zied, K. (2008). Stock exchange demutualization, self-listing and performance: The case of the Australian Stock Exchange. Journal of Banking and Finance, 32, 512-525.

29. Pirrong, C. (2000). A Theory of Financial Exchange Organization. Journal of Law and Economics, 43, 437-471.

30. Reiffen, D., \& Robe, M. (2011). Demutualization and customer protection at self-regulatory. The Journal of Futures Markets, 31, 126-164.

31. Schmiedel, H. (2001). Technological development and concentration of stock exchanges in Europe. Discussion Papers No. 21/2001, Bank of Finland, Helsinki.

32. Schmiedel, H. (2002). Total factor productivity growth in European stock exchanges: A non-parametric frontier approach, Discussion Papers No.11/2002, Bank of Finland, Helsinki.

33. Shleifer, A., \& Vishny, R.W. (1997). A survey of corporate governance. The Jounal of Finance, 52, 737783.

34. Serifsoy, B. (2008). Demutualization, outsider ownership, and stock exchange performance: empirical evidence, Economics of Governance, 9, 305-339.

35. Steil, B. (2002). Changes in the ownership and governance of securities exchanges: Causes and consequences. In R. E. Litan \& R. Herring (Eds.), Brookings-Wharton papers on financial services 2002 (pp. 61-82). Washington DC: Brookings Institution Press.

36. Treptow, F. (2006). The economics of demutualization: An empirical analysis of the securities exchange industry. Wiesbaden: Springer.

37. Tricker, B. (2012). Corporate governance: principles, policies and practices. Oxford: Oxford University Press.

38. World Federation of Exchanges (WFE). 2000-2011. Annual Reports.World Federation of Exchanges (WFE). 1998-2011. Cost and revenue Survey.

39. Worthington, A., \& Higgs, H. (2006). Market risk in demutualized self-listed stock exchanges: An international analysis of selected time-varying betas. Global Economic Review, 35, 239-257. 
NOTES 